\title{
The effect of REACT strategy assisted by GeoGebra software on students' mathematical representation ability
}

Nurzannah, Muliana*, Herizal, Fajriana, \& Mursalin

Department of Mathematics Education, Universitas Malikussaleh, Aceh Utara, Indonesia

*Corresponding author: muliana.mpd@unimal.ac.id | Phone Number: +6282361547580

\section{ARTICLE INFO}

Received: 05-08-2021

Received in revised: 20-09-2021

Accepted: 28-09-2021

Available online: $30-10-2021$

\section{KEYWORDS}

Mathematical Representation Ability;

Geogebra Software;

REACT Strategy;

\section{A B S T R A C T}

This study was conducted to determine the effect of REACT strategy assisted by GeoGebra software on students' mathematical representation ability. This study was quasi-experimental with a quantitative approach. The design used in this study was The Nonequivalent Posttest Only Control Group Design. Four posttest questions were given to 25 students of Class VIII A and 25 students of Class VIII B at SMP Negeri Arun Lhokseumawe (public middle school). The data obtained from the posttest results were analyzed by data normality test and data homogeneity test, then hypotheses were tested using a t-test to see the effect of REACT strategy assisted by GeoGebra software on students' mathematical representation ability. The results of the data analysis of the posttest score tested using the t-test, the sig value was obtained. (2-tailed) of $0.000>0.05$. This showed that there was a significant effect of using the REACT strategy assisted by GeoGebra software on students' mathematical representation ability.

\section{INTRODUCTION}

Mathematics lessons are included in one of the most important lessons and listed in the learning curriculum in schools, from elementary, secondary to higher levels, even mathematics is also taught in college. This is because mathematics is a science that has an important role in human life. The development of technology and other sciences also involves the use of mathematics. Seeing the importance of the role of mathematics, learning mathematics is considered as one of the efforts to prepare quality Human Resources (HR) and able to contribute to the development of technology and science.

According to the National Council of Teachers of Mathematics (NCTM, 2000) there are five basic abilities that are used as standards in the mathematics learning process, namely problem solving, reasoning and proof, communication, connection, and representation. Based on NCTM, it can be seen that one of the mathematical abilities that must be possessed by students is the representational ability. The ability is very important for students to be able to express their ideas as stated by NCTM (2000):
"Mathematical ideas can be represented using: pictures, concrete objects, tables, graphs, numbers, letter symbols, spreadsheet views, and so on. How to represent mathematical ideas is the basis for how someone understands and uses these ideas. When students have mathematical representational ability and the ideas they express and when they can create representations to capture mathematical concepts or relationships, they acquire a set of tools that significantly expand their ability to model and interpret physical, social, and mathematical phenomena".

According to Mandur et al., (2016:67) mathematical representation ability is the ability to express mathematical ideas or ideas in the form of pictures, graphs, tables, diagrams, mathematical equations or expressions, symbols, writing or written words. Mathematical representation needs to be the focus of attention in learning mathematics, because through representation students can convey mathematical ideas and solve problems in mathematics. That was in line with the opinion of Ruzi and Muzakir (2015: 7) which stated that representation is a form of expression of mathematical ideas displayed by students as - 
models or substitute forms of a problem situation that used to find solutions to the problems they are facing as a result of the interpretation of their thoughts. The interpretation could be in the form of pictures, words (verbal), tables, concrete objects, or mathematical symbols. From the statement above, it can be concluded that the ability of mathematical representation can be used as a tool to communicate, reason and solve problems in mathematics.

However, in fact students' mathematical representation ability was still low, as happened at SMP Negeri Arun Lhokseumawe (Public Middle School). Based on the results of observations at SMP Negeri Arun Lhokseumawe on 2 February 2021 by conducting interview with math teachers and students in class VIII, there were still students who were confused in representing their ideas in learning mathematics. This happens because of several factors, including the teaching method that was still teachercentered. Although the learning approach used was a scientific approach, in reality learning was still teachercentered. The teacher conveyed the material by providing formulas, theories and asking students to take notes and memorize the material. Furthermore, in working on practice questions, students tend to follow the steps in the examples given by the teacher, so that students were less creative in representing their ideas with new steps when solving problems. Students were not accustomed to having discussions with the teacher about material that has not been understood. Another factor was the use of learning media that has not been maximized, this was in accordance with student responses that during the learning process rarely use auxiliary media other than textbooks.

Facts in the field showed that there were still many students who were confused in representing their ideas in solving a mathematical problem. This can be seen from the results of the mathematical representation ability test that has been carried out by researchers in class VIII B. From the test results, it can be seen that there were still many students who are confused, so they need to be guided to be able to express their ideas in answering test questions. The following is a description of the questions and answers from students carried out by class VIII B students:

Putri mothers will build a badminton court in her front yard. If the length of the court is 18 meters and the width is $2 / 3$ of the badminton court that will be made by Putri mothers

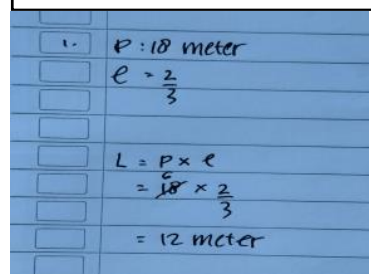

Student do not describe a rectangular picture to clarify the problem and facilitate completion, besides that students are still confused in determining the width of the problem presented.
The low ability of students' mathematical representation was in accordance with the results of research that has been carried out by several experts. That was caused by several factors, such as the use of methods, models and learning media that are less innovative, learning was still teacher-centered, and students are not given the opportunity to represent their ideas (Hutagaol, 2013: 86; Yusnita, 2016:30; Listiana, 2018: 2-3).

Furthermore, students' low mathematical representation ability was also seen from students' difficulties in making symbols, presenting information from questions in the form of pictures, mathematical models and words in solving word problems. That was because students are used to memorizing formulas and will find it difficult if given non-routine questions (Armadan, 2017:51; Sulistyowaty, 2019:154-155), the teacher only focuses on training students to work on questions to get a high score on the final exam, but mastery of student material still lacking (Mulyati, 2016:37-38).

To overcome the problem, an approach should be taken in the learning process, in accordance with the opinion of Deviana and Pramartha (2020:52) which states that to improve students' mathematical representation skills, an innovative learning approach was needed and could attract students' interest to be actively involved during the learning process. The approach that could be taken was by using appropriate strategies and media in order to improve students' mathematical representation abilities. One of the appropriate strategies to use is the REACT strategy.

REACT is an acronym for the words Relating, Experiencing, Applying, Cooperating, and Transferring. Learning with the REACT strategy according to Rohaeti et al., (2019: 205-206) is the development of contextual learning that emphasizes the activities of students finding the concepts they are learning, students working in small groups, applying these concepts in everyday life and transferring the concepts that have been obtained into new conditions. Furthermore, in the Center for Occupational Research and Development (CORD, 1999) it is stated that REACT learning contains five main activities, including:

(1) Relating is connecting the concepts learned with something that students already know. (2) Experiencing is a hands-on activity and support environment that allows students to build new knowledge based on the knowledge they already have. (3) Applying, namely when students apply their knowledge to real world situations. (4) Cooperating is working together to learn in the context of sharing, responding, and communicating with other students. Furthermore, (5) Transferring occurs when students accept what they have learned and apply it to new situations and contexts.

Figure 1. Test of Mathematical Representation Questions 
The learning component of the REACT strategy provides opportunities for students to improve their mathematical representation ability. Especially at the applying stage (using or applying) students were asked to use the concepts they have in solving a given problem. Furthermore, students were also required to be able to represent their ideas at the transferring stage. At the transferring stage, students asked to be able to use the knowledge they have acquired in new situations.

The use of the REACT strategy to overcome the low mathematical representation ability of students is supported by the results of research conducted by Sari et al., (2017) which showed that the increase in the mathematical representation ability of students who receive learning with the REACT strategy was higher than students who received conventional learning. Furthermore, the results of research Wulandari et al., (2018) which concluded that (1) Student activity shows active students with good criteria. (2) There was an increase in students' mathematical understanding and mathematical representation skills in learning using the REACT strategy. (3) There was a correlation between the ability of understanding and mathematical representation in learning with the REACT strategy of 0.918 with very high criteria. (4) Completeness of student learning with a KKM score of 75 or a minimum score of $80 \%$ of the number of students 40 as many as 35 students completed and 5 students have not completed. (5) Students' responses to learning with the REACT strategy were strong. So it can be concluded that the REACT strategy applied in learning can increase student activity, improve students' mathematical understanding and representation abilities.

In addition to using the right model, learning media also plays an important role for students in representing mathematical ideas when solving a problem. In accordance with the opinion of Oktaria et al. (2016: 100) which stated that one of the factors that affect students' mathematical representation abilities was the use of learning media that could support students in visualizing or representing mathematical problems. To overcome this problem, an attempt was made to use learning media to help students understand the material and affect the students mathematical representation ability.

According to Nur (2016:12) the use of computers in the education sector was not only a tool that was only used for administrative matters, but could also be used as an alternative in the selection of learning media. One of the computer programs that could be used in learning is the use of learning software. In the field of mathematics there are several learning software such as GeoGebra, Autograph, SPSS, Wingeom, and so on.

Pianda (2016:275) says that GeoGebra is a mathematical software that can be used widely and has the ability to handle variables for numbers, vectors and points, find derivatives and integral functions. Furthermore, Nur (2016:12) said that the GeoGebra Software was developed for the teaching and learning process of mathematics in schools which has at least three uses, namely; as a medium for learning mathematics, tools for making mathematics teaching materials, and solving math problems.

Several previous studies on the use of GeoGebra in mathematics lessons, such as (Rahmawati, 2019; Pratiwi, 2016; Lestari, 2018) that the most effective learning media in teaching mathematics is by using GeoGebra software. This has also been shown to improve students' mathematical problem-solving abilities (Septian, 2017). In addition, the ability to understand of mathematical concepts is also increased by using GeoGebra teaching materials (Lestari, 2018). The effectiveness of using GeoGebra software in teaching and learning mathematics is also shown by the research of Bakar et al., (2010a) that this software can make students explore and understand mathematical material. Student-centered learning models with good teacher instructional designs and softwareassisted students are theoretically able to understand the subject matter (Bu et al., 2011; Azizul \& Din, 2018; Arbain \& Shukor 2015; Bakar et al., 2010b). This is because mathematics requires motivation to learn difficult material, so the use of attractive ICT software triggers students' enthusiasm to learn (Zulnaidi \& Zakaria, 2012; Haciomeroglu et al., 2009).

The use of GeoGebra software in an effort to overcome the low mathematical representation ability of students was supported by the results of research conducted by Oktaria et al., (2016) which showed that the use of GeoGebra software media could improve students' mathematical representation skills on the material of a two-variable linear equation system (SPLDV). The factors that influence the increase in mathematical representation skills using GeoGebra are can display graphs of line equations clearly, accurately and quickly. Therefore, based on the description above, the researchers are interested on conduct research entitle "the effect of REACT strategy assisted by GeoGebra software on students' mathematical representation ability".

\section{METHOD}

The research approach used in this study was a quantitative approach. According to Sugiyono (2018:8) a quantitative research approach can be interpreted as a research approach used to examine a particular population or sample, data collection using research instruments, data analysis is quantitative/statistical, with the aim of testing the established hypothesis. The type of research used in this study was quasi-experimental. Quasi-experimental research is used because in reality it is difficult to get a control group used for research (Sugiyono, 2018: 77). The research design used in this study was The Non-equivalent 
Posttest Only Control Group Design (Lestari and Yudhanegara, 2018:136) which could be described in the Figure 2.

\begin{tabular}{|c|c|}
\hline $\mathrm{X}$ & $\mathrm{O}_{1}$ \\
\hline & $\ldots \ldots$ \\
& $\mathrm{O}_{2}$ \\
\hline
\end{tabular}

Figure 2. The Nonequivalent Posttest Only Control Group Design

Note:

$\mathrm{X}$ : The treatment given in the experimental class

01 : Posttest experiment class

02 : Posttest control class

- - - : The sample is not taken at pure random

This study was conducted at the SMP Negeri Arun Lhokseumawe (public middle school) which is located on Jl. Comp. Arun, West Batuphat, Muara Satu, Lhokseumawe City, Aceh, in the even semester of the 2020/2021 academic year. The population in this study were all eighth grade students at SMP Negeri Arun Lhokseumawe. The sampling technique used in this study is a purposive sampling technique, which is a sampling technique carried out with several considerations (Lestari \& Yudhanegara, 2018: 110). The samples in this study were students of class VIII A as the experimental class and class VIII $\mathrm{B}$ as the control class. The reason of chosing the class was classes have the same mathematical ability (homogeneous). In addition, both classes also have projector facilities.

This study used two research variables, namely the independent variable which in this study is the strategy of
Relating, Experiencing, Applying, Cooperating, Transferring (REACT) assisted by Geogebra software and the dependent variable namely the ability of students' mathematical representation. The data collection technique used a test in the form of a posttest which consists of 4 questions essay. The questions used were first validated by conducting several tests, namely validity test, reliability test, discriminatory power test and difficulty index test.

The data analysis of the instrument test includes validity test, reliability test, discriminatory power test and difficulty level test. The purpose of this data analysis is to see whether the test instrument is suitable for use in the study. The test instruments that were tested and analyzed were 7 items in the form of descriptions. This instrument trial was conducted in class VIII MTs PP. Al-Wasliyah Tanjung Haloban with a total of 26 students. Of the 7 questions that were tested for validity, reliability, discriminatory power, and level of difficulty, there were 4 questions that met the requirements and deserved to be used. The following are the guidelines for scoring students' mathematical representation abilities in the Table 1.

After giving the posttest questions to the experimental class and control class, the posttest value data were obtained. Furthermore, an analysis of the data was carried out using data analysis techniques. Data analysis techniques were carried out to analyze the data used and draw conclusions from the sample data so that the results could be applied to the population. The tests carried out to analyze the data in this study were started with normality and homogeneity tests, then continued with hypothesis testing using t-test.

Table 1.Scoring Criteria for Students' Mathematical Representation Ability

\begin{tabular}{|c|c|c|c|}
\hline Score & Visual/image representation & Representation of words or written text & $\begin{array}{c}\text { Representation of mathematical equations } \\
\text { or expressions }\end{array}$ \\
\hline 0 & & No answer & \\
\hline 1 & $\begin{array}{l}\text { Just a few of the pictures, diagrams } \\
\text { are correct }\end{array}$ & Inaccurate explanation & Inadequate representation \\
\hline 2 & $\begin{array}{l}\text { Painting diagrams, pictures but not } \\
\text { complete and correct }\end{array}$ & Only a few of the correct explanations & $\begin{array}{l}\text { Only a few of the mathematical models are } \\
\text { correct }\end{array}$ \\
\hline 3 & $\begin{array}{l}\text { Complete and correct drawing } \\
\text { diagrams, but still not perfect }\end{array}$ & $\begin{array}{l}\text { The explanation is mathematically reasonable and } \\
\text { correct, even though it is not logically arranged or } \\
\text { there are few language errors }\end{array}$ & $\begin{array}{l}\text { Finding the right mathematical model but } \\
\text { wrong in getting the solution }\end{array}$ \\
\hline 4 & $\begin{array}{l}\text { Complete and correct drawing } \\
\text { diagrams }\end{array}$ & $\begin{array}{l}\text { Mathematical explanations are reasonable and clear } \\
\text { and logically arranged }\end{array}$ & $\begin{array}{l}\text { Determine the mathematical model } \\
\text { correctly then perform calculations or get } \\
\text { the correct solution }\end{array}$ \\
\hline
\end{tabular}

Modification of Chai, Lane and Jacabscin (in Fonna, 2013:33)

\section{RESULTS AND DISCUSSION}

\section{Results}

In this study, it will be seen whether there is an effect of Relating Experiencing, Applying, Cooperating, Transferring (REACT) strategy assisted by GeoGebra software on students' mathematical representation ability from posttest data. Based on the results of the research conducted, the data obtained from the posttest results from the experimental class and the control class.

After obtaining the posttest score data, it will be analyzed whether there was an effect of using the REACT strategy assisted by GeoGebra software on students' mathematical representation ability. The analysis was 
carried out using the data normality test, data homogeneity test, and statistical hypothesis testing using the t-test.

\section{Normality test}

Normality test is a test carried out with the aim of seeing whether the distribution of data is normally distributed or not. The normality test used in this study was the ShapiroWilk test using IBM SPSS 25 software. The criteria for the normality test hypothesis were that the data was normal if sig. $\geq \alpha$, with $\alpha=0.05$. The results of the posttest normality test for the control class and the experimental class showed in the table 2 .

Based on the table 2, it can be seen that the significant value of the experimental class is 0.432 and the significant value of the control class is 0.073 . In accordance with the hypothesis criteria mentioned above, it can be seen that the significant value of the experimental class $=0.432 \geq 0.05$ as well as the significant value of the control class $=0.073 \geq$ 0.05. Based on the data from the students' mathematical representation ability test results, it can be concluded that the data is normally distributed.

\section{Homogeneous Test}

Homogeneity test is a test that aims to see whether the data from the analyzed sample has the same variance (homogeneous) or not. This test was carried out using Levene statistical test assisted by IBM SPSS 25 software. The criteria for drawing conclusions in this test were that the data was homogeneous if the sig. $\geq \alpha$, with $\alpha=0.05$. The The results of the homogeneity test of the posttest scores for the control class and the experimental class showed in the table 3 .
Based on the table 3 , it can be seen that the significant value of the data from the student's mathematical representation ability test is 0.067 . In accordance with the criteria for drawing conclusions from the hypothesis test, it could be seen that the data from the mathematical representation ability test is homogeneous because the value of sig. $=0.067 \geq 0.05$.

\section{Hypothesis testing}

After the normality test and homogeneity test were carriedout, the hypothesis was tested. Hypothesis testing in this study uses a two-sample independent t-test which aims to see the effect of mathematical representation ability between students who apply the REACT strategy assisted by GeoGebra software and students who use a scientific approach. The results of the hypothesis test using the IBM SPSS 25 software in the table 4.

Based on the table 4 , it can be seen that the statistical significance value obtained from the t-test is 0.000 , so the value of sig. $<0.05$. In accordance with the hypothesis test criteria, if the significance value is $\geq 0.05$, then $\mathrm{HO}$ is accepted, whereas if the significance value is $<0.05$, then $\mathrm{HO}$ is rejected. For this study it can be concluded that the results of hypothesis testing in this study are $\mathrm{HO}$ rejected. This means that there is a significant difference in the average mathematical representation ability of students who use the REACT strategy assisted by GeoGebra software compared to the average mathematical ability of students who receive scientific learning. Based on this, it can be concluded that there is an effect of using the REACT strategy assisted by GeoGebra software on students' mathematical representation ability.

Table 2. Normality Test Results of Mathematical Representation Ability Data

\begin{tabular}{cccc}
\hline & \multicolumn{2}{c}{ Tests of Normality } & \\
\hline & & Shapiro-Wilk \\
\cline { 2 - 4 } & Statistic & Df & 25 \\
\hline Eksperiment Class & 0,961 & 25 & 0,432 \\
\hline Control Class & 0,927 & 0,073 & 25 \\
\hline
\end{tabular}

Table 3. Results of Homogeneity Test of Mathematical Representation Ability

$$
\text { Test of Homogeneity of Variances }
$$

\begin{tabular}{cccccc}
\hline & Levene Statistic & $d f 1$ & $d f 2$ & Sig. \\
\hline Posttest Results & Based on Mean & 3,520 & 1 & 48 & 0,067 \\
\hline
\end{tabular}

Table 4. Results of t-test of Mathematical Representation Ability Data Independent Samples Test

\begin{tabular}{|c|c|c|c|c|}
\hline \multicolumn{5}{|c|}{ Independent Samples Test } \\
\hline & & \multicolumn{3}{|c|}{ t-test for Equality of Means } \\
\hline & & $t$ & $D f$ & Sig. (2-tailed) \\
\hline Posttest Result & Equal variances assumed & 5,243 & 48 & 0,000 \\
\hline
\end{tabular}

\section{Discussion}

This study was conducted with the aim of knowing whether there is an effect of using the REACT strategy assisted by GeoGebra software on the mathematical representation ability of students in class VIII SMP N Arun Lhokseumawe.
In this study, the researchers used the REACT strategy assisted by GeoGebra software when doing learning in the experimental class, while in class control researchers using a scientific model approach. The use of GeoGebra software in this study was intended so that students could get direct 
experience of how the elements of cubes and cuboid are, how to find the surface area and volume of cubes and cuboid. Visual experiences presented through GeoGebra media were expected to provide deep understanding, and make it easier for students to represent their ideas in solving mathematical problems.

Based on the results of the study and the results of the analysis of statistical test calculations for the two classes, it was concluded that the used of REACT strategy assisted by GeoGebra software significantly affected students' mathematical representation ability. That could be seen from the results of the average posttest value obtained by the experimental class of 33.4 , which is greater than the average value obtained by the control class of 22.44. The results obtained in this study are in line with the results of research conducted by Jaliah, et al., (2017) which stated that learning with a contextual approach with the REACT strategy was significantly better than conventional learning in improving students' mathematical representation ability. The same thing was also found in the research conducted by Kusumawati (2017) which stated that the achievement of mathematical representation abilities of students who received learning through the REACT strategy with an open-ended approach was better than students who received conventional learning. Based on these results, it can be concluded that learning using the REACT strategy have an effect on students' mathematical representation ability.

The uniqueness of this study was that the learning was carried out using the GeoGebra software media. The effect of using GeoGebra software on students' mathematical representation ability was in line with several previous research results. As the results of study conducted by Kamilah et al., (2019) which concluded that there was an increase in the mathematical representation ability of students who received Problem Based Learning (PBL) model assisted by GeoGebra software better than students who received conventional learning. The same thing was also obtained from the research of Fasa et al., (2020) which showed that the increase in the mathematical representation ability of students who received the GeoGebra-assisted PBL model was higher than students who received the expository model. Furthermore, the results of Rahmawati's research (2021) showed that the percentage of students' mathematical representation ability who received learning using the GeoGebra-assisted Guided Note Taking method always increases in each learning cycle. This shows that learning assisted by GeoGebra software has an effect on students' mathematical representation ability.

During the teaching and learning process in the experimental class using the REACT strategy, the students looked active and enthusiastic. Students try to connect their knowledge of cubes and cuboid with daily situation.
Students gain hands-on experience from the visualizations displayed on GeoGebra to understand the elements of cubes and cuboid and discover the concepts of surface area and volume of cubes and cuboid. While in the control class, learning used a scientific approach assisted by manipulative in the form of boxes in the form of cubes and cuboid to introduce the elements of the spatial structure.

\section{CONCLUSION}

The results of the study that the researchers conducted in class VIII of SMP Negeri Arun Lhokseumawe showed that there was a difference in the average score of the posttest results between the experimental class and the control class. The average posttest score obtained in the experimental class was 33.4 while the average posttest score obtained by the control class was 24.44 . Based on the results of the study, it can be concluded that there is an effect of using the REACT strategy assisted by GeoGebra software on students' mathematical representation ability.

\section{Acknowledgements}

The authors would like to thank all parties who have assisted in the research and writing of this manuscript so that it deserves to be widely published to the academic community.

\section{REFERENCES}

Arbain, N., \& Shukor, N. A. (2015). The effects of GeoGebra on students-achievement. Procedia-Social and Behavioral Sciences, 172, 208-214. DOI:

https://doi.org/10.1016/j.sbspro.2015.01.356

Armadan, S., \& Indaryanti. (2017). Kemampuan Representasi Matematis Siswa Pada Pembelajaran Berbasis Teori Van Hiele di Materi Segiempat Kelas VII SMP Negeri 1 Indralaya Utara. Jurnal Elemen, 3(1): 40-57. DOI: https://doi.org/10.29408/jel.v3i1.306

Azizul, S. M. J., \& Din, R. (2018). Teaching and learning mathematics on geometry using GeoGebra software via MO0C. Journal of Personalized Learning, 2(1), 40-51. http://spaj.ukm.my/jplearning/index.php/jplearning/article/vie $\mathrm{w} / 31$

Bakar, K. A., Ayub, A. F. M., \& Tarmizi, R. A. (2010a). Exploring the effectiveness of using GeoGebra and e-transformation in teaching and learning Mathematics. In Proc. of Intl. Conf. of Advanced Educational Technologies EDUTE (Vol. 2, pp. 1923). www.wseas.us/elibrary/conferences/2010/Tunisia/EDUTE/EDUTE-02.pdf

Bakar, K. A., Ayub, A. F. M., Luan, W. S., \& Tarmizi, R. A. (2010b). Exploring secondary school students' motivation using technologies in teaching and learning mathematics. Procedia-Social and Behavioral Sciences, 2(2), 4650-4654. DOI: https://doi.org/10.1016/j.sbspro.2010.03.744

Bu, L., Spector, J. M., \& Haciomeroglu, E. S. (2011). Toward modelcentered mathematics learning and instruction using GeoGebra: A theoretical framework for learning mathematics with understanding. In Model-Centered 
Learning (pp. 13-40). Brill Sense.

https://brill.com/view/book/edcoll/9789460916182/BP000004 .xml

CORD. (1999). Teaching Mathematics Contextually: The Cornerstone of Tech Prep. Texas: CORD Communications, Inc.

Deviana \& Pramartha, I. N. B. (2020). Pengaruh Pembelajaran ICI Terhadap Kemampuan Representasi Matematis Siswa ditinjau dari Gaya Kognitif. E-Jurnal Matematika, 9(1): 5156. DOI: https://doi.org/10.24843/MTK.2020.v09.i01.p278

Fasa, I. L., Pratama, D. Y., \& Firmansyah, E. (2020). Peningkatan Kemampuan Representasi Matematis dan Kemandirian Belajar Siswa melalui Model Pembelajaran PBL Berbantuan GeoGebra. Pasundan Journal of Mathematics Education, 10(2): 82-91. DOI:

http://dx.doi.org/10.5035/pjme.v10i2.2741

Fonna, M. (2013). Penggunaan Model Pembelajaran Kooperatif Tipe Cooperative Integrated Reading and Composition untuk Meningkatkan Kemampuan Representasi dan Pemecahan Masalah Matematis Siswa. Tesis. http://repository.upi.edu/6424/

Haciomeroglu, E. S., Bu, L., Schoen, R. C., \& Hohenwarter, M. (2009). Learning to develop mathematics lessons with GeoGebra. MSOR Connections, 9(2), 24-26.

https://www.schoenresearch.com/wp-

content/uploads/2020/08/haciomeroglu_bu_schoen_hohenwarte r_2009_geogebramathlessons.pdf

Hutagaol, K. (2013). Pembelajaran Kontekstual untuk

Meningkatkan Kemampuan Representasi Matematis Siswa Sekolah Menengah Pertama. Jurnal Ilmiah Program Studi Matematika STKIP Siliwangi Bandung, 2(1): 85-99. DOI: https://doi.org/10.22460/infinity.v2i1.p85-99

Jaliah, R., Irawati. R. \& Sujana, A. (2017). Pengaruh Pendekatan Kontekstual Berstrategi Relating, Experiencing, Applying, Cooperating, Transferring (REACT) Terhadap Kemampuan Representasi Matematis Siswa. Jurnal Pena Ilmiah. 2(1): 1091-1100. DOI: https://doi.org/10.17509/jpi.v2i1.11258

Kamilah, S. R., Budilestari, P., \& Gunawan, I. (2019). Penerapan Model Pembelajaran Problem Based Learning (PBL) dengan Berbantuan Geogebra untuk Meningkatkan Kemampuan Representasi Matematis Siswa SMK. Jurnal Pendidikan dan Pembelajaran Matematika, 4(2), 70-77. http://jurnal.fkip.unla.ac.id/index.php/intermathzo/article/view $/ 298$

Kusumawati, A. F.(2017). Pengaruh Pembelajaran Matematika Melalui Strategi REACT dengan Pendekatan Open-Ended Terhadap Kemampuan Representasi Matematis dan Kecemasan Matematika Siswa SMK Di Kota Bandung. Skripsi. http://repository.unpas.ac.id/id/eprint/30400

Lestari, K. E., \& Yudhanegara, M. R. (2018). Penelitian Pendidikan Matematika. Bandung: PT Refika Aditama.

Lestari, I. (2018). Pengembangan bahan ajar matematika dengan memanfaatkan GeoGebra untuk meningkatkan pemahaman konsep. GAUSS: Jurnal Pendidikan Matematika, 1(1), 26-36. DOI: https://doi.org/10.30656/gauss.v1i1.634
Listiana, Y. (2018). Peningkatan Kemampuan Representasi Matematis dan Keterampilan Sosial Siswa Melalui Pendekatan Pembelajaran Matematika Realistik. Jurnal MathEducation Nusantara, 1(1): 1-14. DOI: https://doi.org/10.32696/jmn.v1i1.1

Mandur, K., Sadra. I. W., \& Suparta. I. N. (2016). Kontribusi Kemampuan Koneksi, Kemampuan Representasi, dan Disposisi Matematis terhadap Prestasi Belajar Matematika Siswa SMA Swasta Di Kabupaten Manggarai. Jurnal Pendidikan dan Kebudayaan Missio, 8(1): 65-72. http://jurnal.unikastpaulus.ac.id/index.php/jpkm/article/view/8 4

Mulyati. (2016). Peningkatan Kemampuan Pemahaman dan Representasi Matematis Siswa SMA Melalui Strategi Preview-Question-Read-Reflect-Recite-Review. Jurnal Analisa Prodi Pendidikan matematika UIN Sunan Gunung Djati, 2(3): 36-55. DOI: https://doi.org/10.15575/ja.v2i3.1223

NCTM. (2000). Principles and Standards for School Mathematics. Reston, Va.: NCTM.

Nur, I. M. (2016). Pemanfaatan Program GeoGebra dalam Pembelajaran Matematika. Jurnal Matematika dan Pendidikan Matematika, 5(1): 10-18. DOI: http://dx.doi.org/10.33387/dpi.v5i1.236

Oktaria, M., Alam, A. K., \& Sulistiawati. (2016). Penggunaan Media Software GeoGebra untuk Meningkatkan Kemampuan Representasi Matematis Siswa SMP Kelas VIII. Jurnal Matematika Kreatif Inovatif Unnes, 7(1): 99-107. DOI: https://doi.org/10.15294/kreano.v7i1.5014

Pianda, D. (2016). Penggunaan Media GeoGebra Melalui Pendekatan Scientific untuk Peningkatan Hasil Pembelajaran Matematika. Indonesian Digital Journal of Mathematics and Education, 3(4): 273-284. http://idealmathedu.p4tkmatematika.org

Pratiwi, D. D. (2016). Pembelajaran learning cycle 5E berbantuan geogebra terhadap kemampuan pemahaman konsep matematis. Al-Jabar: Jurnal Pendidikan Matematika, 7(2), 191-202. DOI: https://doi.org/10.24042/ajpm.v7i2.9684

Rahmawati, J. P. (2021). Upaya Meningkatkan Kemampuan Representasi Matematis Siswa dengan Metode Pembelajaran Guided Note Taking Berbantuan GeoGebra. Jurnal Riset Pendidikan Matematika Jakarta. 3(1): 27-35. http://journal.unj.ac.id/unj/index.php/jrpmj

Rahmawati, C. (2019). Pengembangan Media Pembelajaran Matematika Menggunakan Geogebra Dan Microsoft Mathematic Di La Royba Islamic School. JSI (Jurnal sistem Informasi) Universitas Suryadarma, 6(1), 18-30. DOI: https://doi.org/10.35968/jsi.v6i1.272

Rohaeti, E. E., Hendriana, H., \& Sumarmo, U. (2019). Pembelajaran Matematika Bernuansa Pendidikan Nilai dan Karakter. Bandung: PT Refika Aditama.

Ruzi, F., \& Muzakir, U. (2015). Pengaruh Pendekatan Pembelajaran Problem Posing terhadap Kemampuan Representasi Matematika Siswa pada Materi Bangun Datar Segi Empat. Jurnal Numeracy, 2(1): 1-12. DOI: https://doi.org/10.46244/ numeracy.v2i1.141 
Sari, D. P., Darhim, \& Rosjanuardi, R. (2017). Peningkatan Kemampuan Representasi Matematis Siswa SMP dengan Strategi REACT. Jurnal Edukasi Matematika, 8(14): 827883. http://eprints.ulm.ac.id/id/eprint / 6554

Septian, A. (2017). Penerapan Geogebra untuk Meningkatkan Kemampuan Pemecahan Masalah Matematis Mahasiswa Program Studi Pendidikan Matematika Universitas Suryakancana. Prisma, 6(2), 180-191. DOI: https://doi.org/10.35194/jp.v6i2.212

Sugiyono. (2018). Metode Penelitian Kuantitatif, Kualitatif, dan $R \& D$. Bandung: Alfabeta.

Sulistyowaty, R. K., Yaya, S. K., \& Bambang, A. P. (2019). Peningkatan Kemampuan Representasi Matematis Melalui Pembelajaran Collaborative Problem Solving. Jurnal Pendidikan Matematika, 13(2): 153-162. DOI: https://doi.org/10.22342/jpm.13.2.6829.153-162
Wulandari, I. P., Praja, E. S. \& Aminah, N. (2018). Penerapan Strategi REACT pada Kemampuan Pemahaman dan Representasi Matematis Siswa SMP. Prosiding Seminar Nasional Matematika dan Pendidikan Matemataika II. Cirebon: Universitas Swadaya Gunung Jati. http://fkipunswagati.ac.id/ejournal/index.php/snmpm/article/view/410/3 44

Yusnita, I., Masykur, R., \& Suherman. (2016). Modifikasi Model Pembelajaran Gerlach dan Ely Melalui Integrasi Nilai-Nilai Keislaman Sebagai Upaya Meningkatkan Kemampuan Representasi Matematis. Jurnal Pendidikan Matematika, 7(1): 29 - 38. DOI: https://doi.org/10.24042/ajpm.v7i1.29

Zulnaidi, H., \& Zakaria, E. (2012). The effect of using GeoGebra on conceptual and procedural knowledge of high school mathematics students. Asian Social Science, 8(11), 102. DOI: http://dx.doi.org/10.5539/ass.v8n11p102 